Revista Española de Antropología Americana

ISSN: 0556-6533

https://dx.doi.org/10.5209/reaa.75826

\title{
El tono de la ofrenda a los mallkus en el Collasuyu. Correlatos arqueológicos para imágenes de flautas en Guamán Poma (siglos XIV-XVI)
}

\author{
Mónica Gudemos ${ }^{1}$ y Helena Horta Tricallotis ${ }^{2}$
}

Recibido: 2 de mayo de 2021 / Aceptado: 26 noviembre 2021

Resumen. Este trabajo aborda el análisis de un objeto óseo arqueológico procedente de Chiuchiu (río Loa, norte de Chile), perteneciente hoy a la colección del Museo de América de Madrid. Su estudio musicológico y contextual -así como su correspondiente comparación con otros objetos óseos similares-, nos permite presentar aquí las argumentaciones por las cuales consideramos que dicho objeto podría tratarse de una flauta como las dibujadas por Guamán Poma en relación con ritos del Collasuyu, en su obra Nueva Corónica y Buen Gobierno (1615). La correlación que aquí establecemos entre este tipo de flauta y otros elementos arqueológicos referidos al atuendo y los adornos personales de los individuos retratados, nos permiten proponer que la flauta tubular bi-diametral habría sido propia del acervo musical de los Colla y de su especial estética sonora. Con ello establecemos, por una parte, una marcada diferencia cultural respecto de la flauta longitudinal tipo quena y, por otra parte, ampliamos el conjunto de objetos ya conocidos como indicadores de la filiación altiplánica. Así, proponemos que esta flauta ósea habría sido el instrumento musical utilizado en las ceremonias y ritos llevados a cabo por los señores del Collasuyu, tanto en tiempos preincaicos como bajo el dominio del Tawantinsuyu.

Palabras clave: Guamán Poma; Fiestas de los Collasuyus; flautas rituales Colla.

\section{[en] The Tone of the Offering to the Mallkus in the Collasuyu. Archaeological Correlation for Images of Flutes in Guaman Poma (XIV-XVI Centuries)}

\begin{abstract}
The starting point of this paper is the analysis of an archaeological bone object from Chiuchiu (Loa River, northern Chile), which belongs today to the collection of the Museo de América in Madrid. Its musicological and contextual study -as well as its corresponding comparison with other similar bone objects- allows us to present here the arguments for which we consider that this object could be a flute like the ones drawn by Guamán Poma in relation to the rites of the Collasuyu, in his work Nueva Corónica y Buen Gobierno (1615). The correlation that we establish here between this type of flute and other archaeological elements referring to the clothing and personal adornments of the individuals portrayed, allow us to propose that the bi-diametral tubular flute would have been part of the musical heritage of the Colla ethnic group and its special sound aesthetics. With this we establish, on the one hand, a marked cultural difference with respect to the longitudinal flute of the quena type, and on the other hand, we expand the set of objects indicative of Colla affiliation. In this way, we propose that this bone flute would have been the musical instrument used in the ceremonies and rites carried out by the Lords of the Collasuyu, both in pre-Inca times and under the rule of the Tawantinsuyu.
\end{abstract}

Keywords: Guamán Poma; Feast of the Collasuyus; Colla ritual flutes

1 Universidad Nacional de Córdoba (Argentina). Secretaría de Ciencia y Tecnología (SeCyT). mgudemos@gmail.com.

2 Instituto de Investigaciones Arqueológicas y Museo R.P. Gustavo Le Paige S.J., Universidad Católica del Norte, San Pedro de Atacama, Chile. hhorta@ucn.cl. 
Sumario. 1. Introducción; 2. La evidencia arqueológica. Aspectos técnicos. 3. La comunicación visual de Guamán Poma. 4. La interpretación cultural de la evidencia arqueológica en el contexto sonoro. 5. Conclusión. El sonido de la ofrenda a los mallkus. 7. Referencias.

Cómo citar: Gudemos, Mónica y Helena Horta Tricallotis. 2022. "El tono de la ofrenda a los mallkus en el Collasuyu. Correlatos arqueológicos para imágenes de flautas en Guamán Poma (siglos XIVXVI)”. Revista Española de Antropología Americana 52 (1): 59-80.

\section{Introducción}

Durante nuestro análisis del material arqueológico depositado en el Museo de América de Madrid con las colecciones asignadas a la Comisión Científica del Pacífico (1862-1865) (Sánchez y Verde 2003), nos detuvimos específicamente en el análisis de los instrumentos musicales de hueso procedentes del norte de Chile ${ }^{3}$. Asimismo, y con la finalidad de profundizar en la comprensión cultural de los productores sonoros, hicimos lo propio con las tecnologías constructivas observadas en otros objetos relacionados contextualmente. Particularmente interesante resultó un objeto, identificado MAM 13446, cuya estructura de huesos embutidos no era desconocida para nosotras, puesto que ya habíamos analizado ejemplares semejantes procedentes de las regiones de Puna y Quebrada de Humahuaca en el Noroeste Argentino (Gudemos 1998a, 2009). Este objeto habría sido excavado en 1864 por Manuel Almagro en Chiuchiu, río Loa, Región de Antofagasta, Chile ${ }^{4}$ (Figura 1).

Previamente, cuando analizamos en el Museo Dr. Eduardo Casanova (Tilcara, Jujuy, Argentina) la posible funcionalidad acústica de las estructuras tubulares de huesos embutidos, procedentes del Noroeste Argentino (NOA), una de ellas era semejante al objeto de Chiuchiu que aquí estudiamos, pero en aquel entonces la consideramos receptáculo o contenedor (Gudemos 1998a: 82-87), e incluso "cetro" (Gudemos 2009: 205), al tomar en cuenta los datos publicados por Antonio Serrano (1930) acerca del hallazgo de Salinas Grandes que tratamos a continuación. Nos referimos a la estructura del objeto procedente de Doncellas $\mathrm{N}^{\circ} 1609$ que en este trabajo analizamos por estudio comparativo. No obstante, ante la existencia de perfiles de diseño compatibles con la emisión de sonido, tuvimos en aquella oportunidad la previsión de dejar interrogantes abiertos, tanto tecnológicos como contextuales. En efecto, si bien observábamos ciertas características constructivas que bien podían aplicarse a la manufactura de instrumentos musicales de soplo (del tipo trompetas o flautas culturalmente asociados a contextos surandinos), otras características no terminaban de convencernos. Actualmente, mediante el estudio comparativo y la búsqueda de tubos análogos llevados a cabo, el análisis del ejemplar del Museo de América comienza a dar respuestas a la mayoría de esos interrogantes, permitiéndonos instalar en la discusión varios argumentos, cada uno de ellos formulados a partir de objetivos específicos y desarrollados en función de marcos metodológicos igualmente específicos.

\footnotetext{
La primera autora de este trabajo realizó en el año 2018 esta actividad financiada por SeCyT, Proyecto de Investigación UNC N $33620180100470 \mathrm{CB}$.

4 Entonces Bolivia. Véase detalles del itinerario de Almagro en Martínez y Sáez 1994: 262.
} 


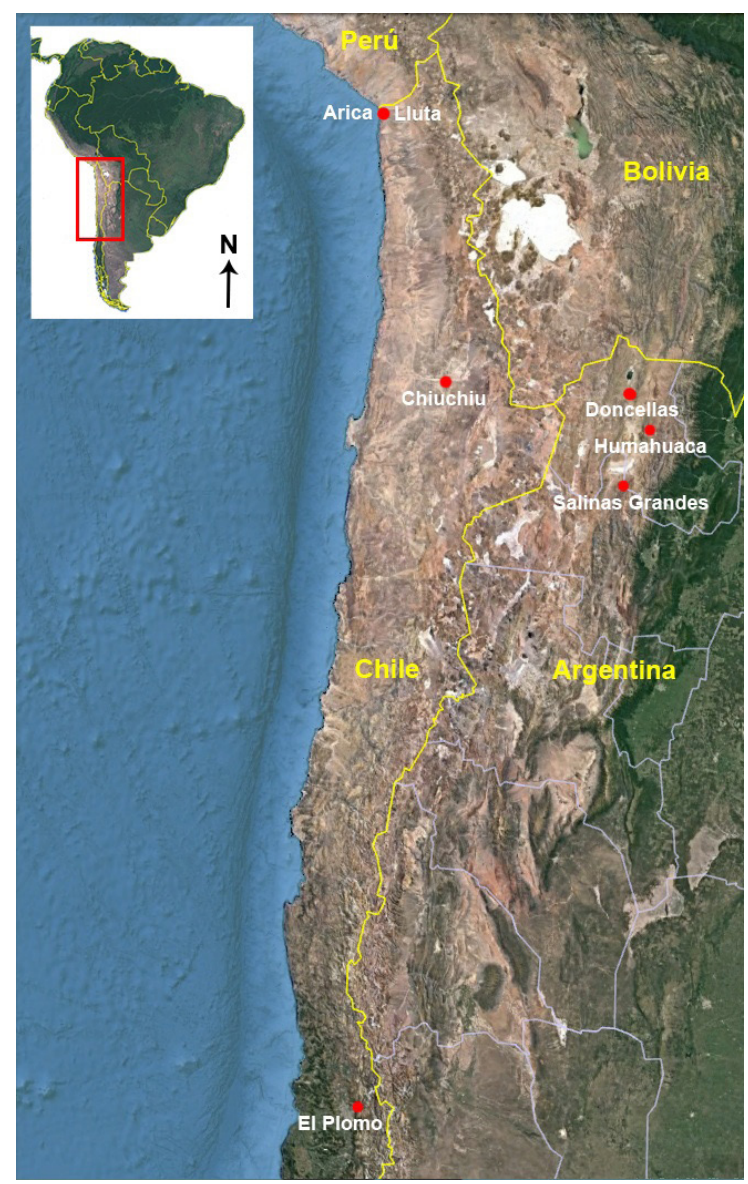

Figura 1. Localización de los sitios arqueológicos mencionados en el texto.

\section{La evidencia arqueológica. Aspectos técnicos}

\subsection{Flauta de hueso de Chiuchiu, río Loa, Antofagasta, Chile}

Tras un minucioso análisis musicológico, hemos clasificado al ejemplar del Museo de América como aerófono longitudinal de tubo bi-diametral [taxón 421.111.21] ${ }^{5}$. Se trata del ejemplar MAM 13446 (Longitud: $168 \mathrm{~mm}$, Ø máximo: $15 \mathrm{~mm}$ ) procedente como ya se dijo de Chiuchiu, ubicado temporalmente según su ficha de inventario entre el 600 y el 1450 d.C. El cuerpo del instrumento está compuesto por dos tubos óseos de diferentes diámetros, cuidadosamente unidos en una firme estructura (Figura 2). El modo en que se aseguró la unión de ambos huesos es relevante para definir su funcionalidad acústica. Precisamente por ello llamó nuestra atención, puesto que pensamos que dicho "seguro de unión" debía responder a una exigencia específica

5 Clasificación taxonómica (sensu Hornbostel y Sachs 1914): aerófono de soplo o flauta, aislado, longitudinal, cerrado, sin canal de insuflación y sin orificios de obturación para el cambio de tono. 
de la función del objeto. El constructor utilizó tiras frescas de tendón, cerámica molida amasada aparentemente con una sustancia de textura talcosa y resina, delgadas varillas de caña y una densa pintura rojiza. Una vez embutido el tubo óseo de menor diámetro en el de mayor diámetro, se fijó el ensamblaje mediante una cobertura de pasta de cerámica molida. Sobre la pasta, seguramente húmeda, se colocaron longitudinalmente las varillas de caña y, a manera de embobinado, se aseguró la unión con las tiras de tendón. Las varillas de caña sirvieron para ajustar y distribuir en forma pareja la presión de los tendones durante el embarrilado, previendo incluso el aumento de presión por contracción de los tendones al secarse. Si bien la estructura de los huesos de camélido (en este caso, sección distal de tibia y sección central de fémur, posiblemente de vicuña, Vicugna vicugna) es firme en sí misma, una fuerte presión ejercida irregularmente puede dañarlos, más aún cuando la pared de la caña de fémur se ve disminuida en su espesor por acción de pulido interno. De allí que la estrategia operativa de usar las varillas de caña no sólo aseguraría la unión, sino que distribuiría longitudinalmente la presión de las ataduras de tendón, ejercida en forma transversal. La pasta de cerámica molida se fue rompiendo con el tiempo, ya sea por la presión de los tendones al secarse o por la misma manipulación del objeto durante su función social activa como aerófono, o bien durante o después de su hallazgo. Se observa el desprendimiento de los pequeños trozos entre las ligaduras (Figura 2.2). También entre ellas puede verse parte del hueso con desprendimiento de pequeñas láminas superficiales, tal vez por acción de descarne. Aparentemente, la sección ósea de menor diámetro no habría sido pulida externamente, como sí lo fue la otra sec-
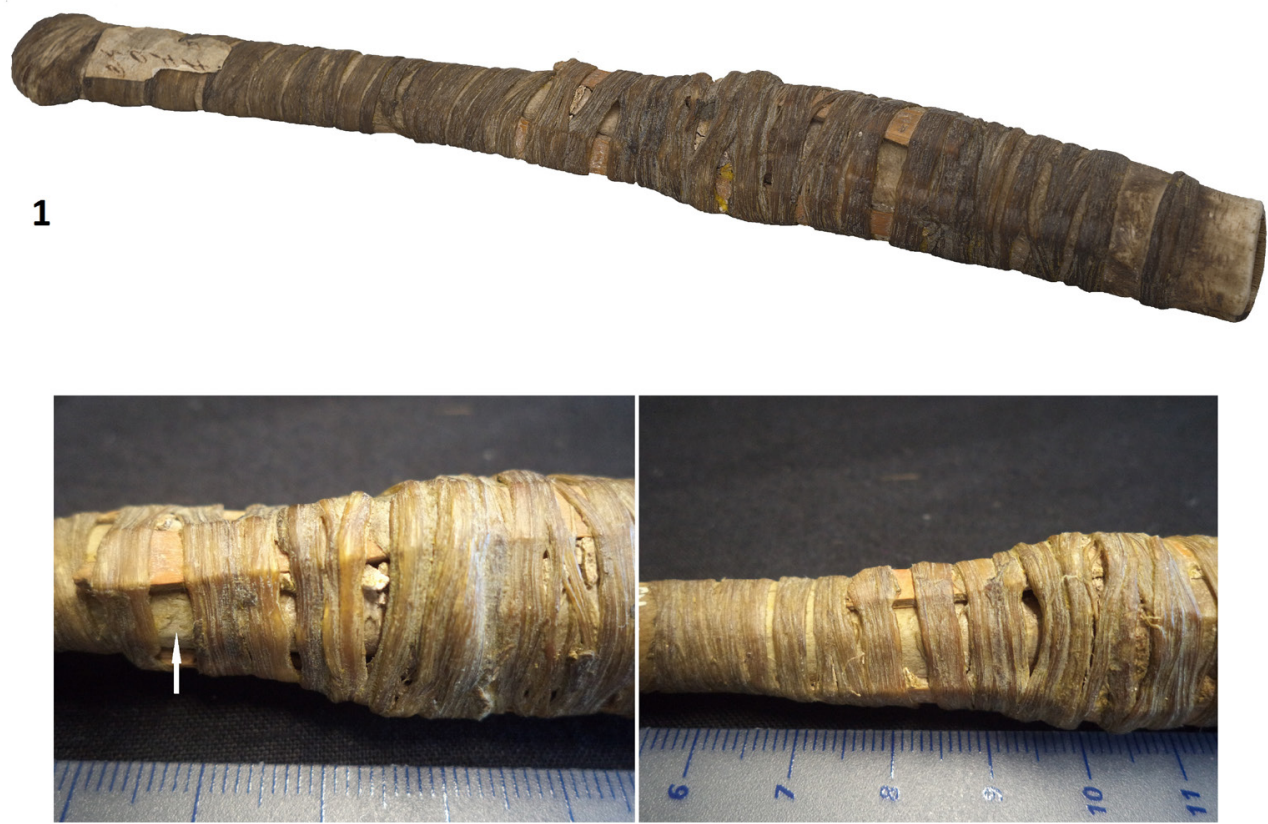

2

3

Figura 2. Flauta ósea bi-diametral MAM 13446 (Museo de América, Madrid): 1) ejemplar completo, longitud $=168 \mathrm{~mm}, \varnothing$ máximo= $15 \mathrm{~mm}$, Chiuchiu, Región del Loa, norte de Chile, 600-1450 d.C. 2) y 3) detalles constructivos (fotografías de Mónica Gudemos). 
ción. Sorprende el sellado del extremo inferior del objeto (Figura 3.2), excelente en su factura y con un acabado de pintura espesa que habría evitado cualquier filtración de aire. Ahora bien, ¿por qué o para qué tomar tantas precauciones en asegurar así una unión de este tipo? Si la función del objeto estudiado fuese un contenedor o un aerófono, se justificarían en ambos casos los recaudos tomados constructivamente. En efecto, si fuese un contenedor para polvos de sustancias psicoactivas o pigmentos, por ejemplo, perderlos por las rendijas sería tan inconveniente como perder el aire en un instrumento musical de viento. Precisamente por esa doble posibilidad funcional del objeto estudiado, nuestro primer objetivo se dirigió a constatar la presencia o ausencia de las particularidades específicas de un aerófono de soplo o flauta.
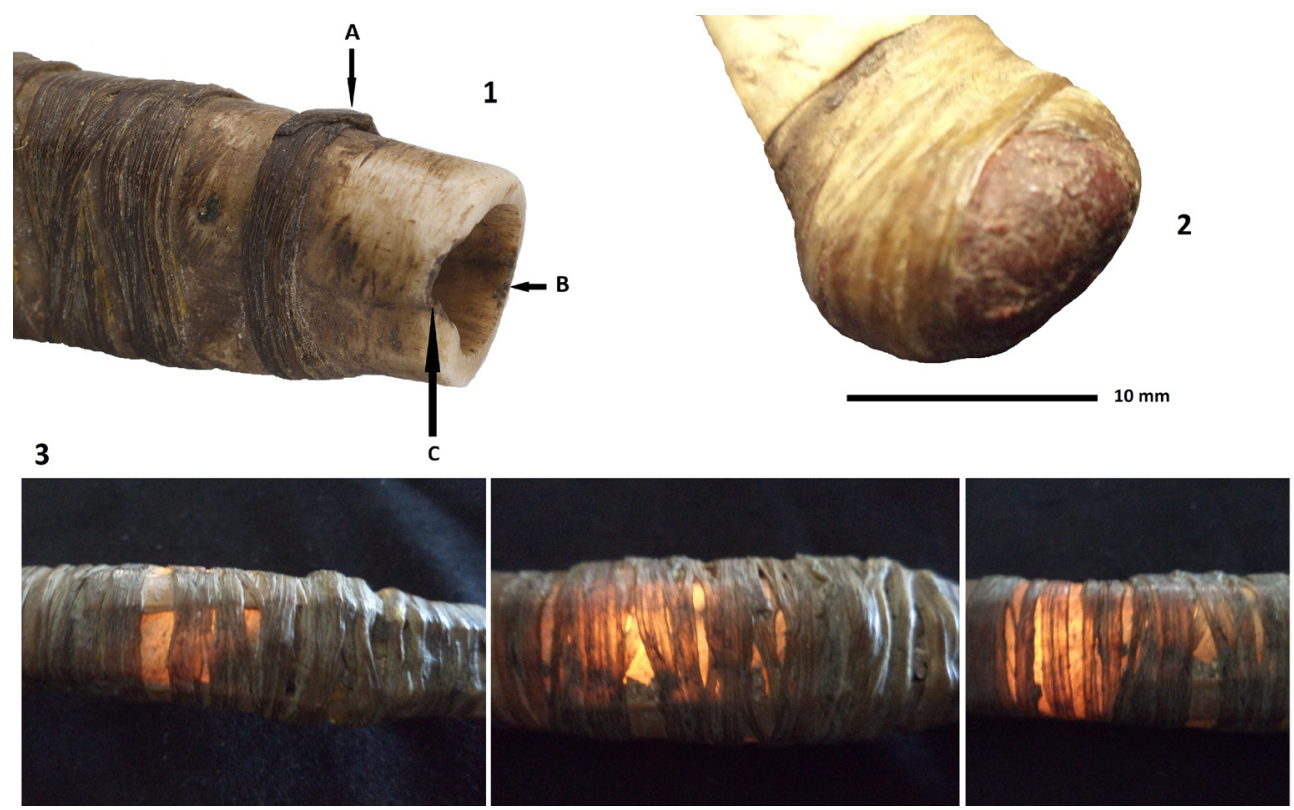

Figura 3. Flauta ósea bi-diametral MAM 13446 (Museo de América, Madrid): 1) detalle del borde de embocadura: A) embobinado simple de tendón para asegurar la estructura en el extremo de embocadura, B) pulido y rebajado del borde de embocadura, C) hendidura y posible punto de impacto que originó la fisura); 2) detalle de obturación del extremo inferior; 3) transparencia lumínica debido al delgado espesor de la pared ósea (fotografías de Mónica Gudemos).

Al respecto, observamos la previsión del constructor en pulir el borde del único orificio (Figura 3.1). Dicho borde posee una muesca (C), diferente en su construcción y acabado frente a las muescas de los aerófonos óseos procedentes de la región andina centro-meridional analizados por nosotras (Gudemos 1998a y b, 2000). Pensamos en primera instancia que podía tratarse de un desprendimiento de material, coincidente con un punto de impacto que produjo la fisura longitudinal. Ahora bien, el perfil de la muesca se dejó sin biselar, lo que no se corresponde con la función acústica propiamente dicha de una hendidura de embocadura: ser un bisel de corte de la corriente de aire del soplo. No obstante, se observan en su contorno el desgas- 
te característico de un uso prolongado y en las irregularidades de su superficie la acumulación de la pátina grasosa propia del calor, la humedad y el contacto con los labios del músico durante la insuflación. Entonces, con respecto a la embocadura de este aerófono, tenemos dos posibilidades: que posea una muesca o hendidura que se dejó sin pulir por la presencia de la fisura o bien que sea un desprendimiento fortuito de material. En este último caso, el instrumento musical tuvo, no obstante, un prolongado uso. La mencionada pátina grasosa se observa igualmente sobre la superficie de la flauta en la misma cara de la muesca (Figura 4.1 A, señalada con corchete), siguiendo la dirección del aire, también característica, que no ingresa al cuerpo tubular tras chocar contra el borde o "filo de embocadura". Las rugosidades de la textura del tendón contribuyeron también a la acumulación de sustancias grasosas. Todo lo observado constituye dato cierto para argumentar la funcionalidad de este orificio como "embocadura" (con o sin muesca) de aerófono sin canal de insuflación 6 .
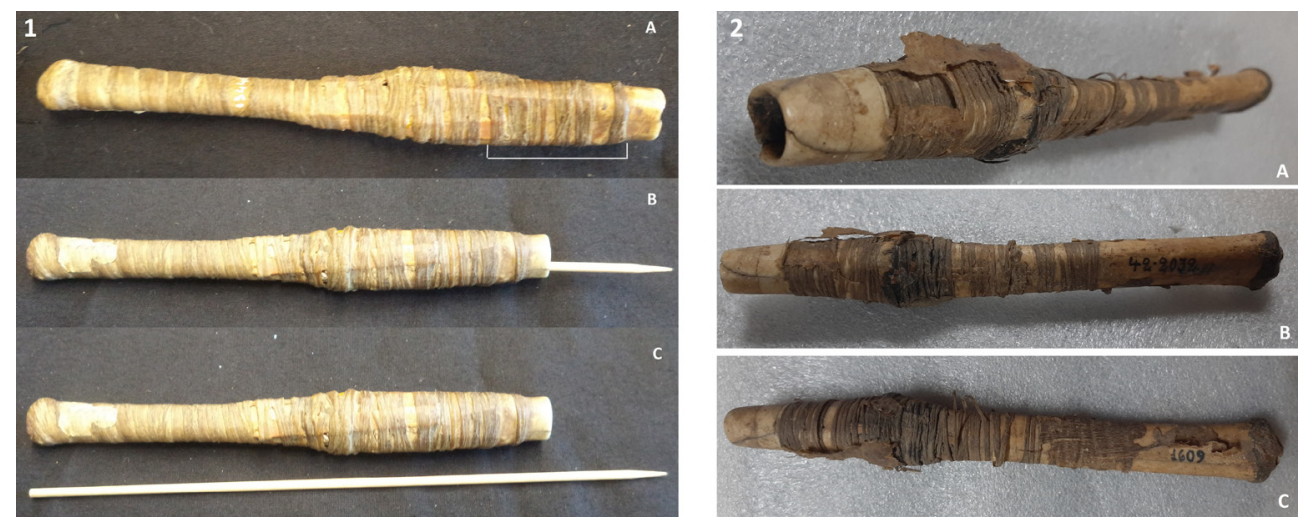

Figura 4. Flautas óseas bi-diametrales: 1) flauta MAM 13446 (Museo de América, Madrid); 2) flauta $\mathrm{N}^{\circ} 1.609$ (Museo Dr. Eduardo Casanova, Tilcara, Jujuy), longitud $=220 \mathrm{~mm}$, Doncellas, Puna de Jujuy, NOA, 1210-1677 d.C. (fotografías de Mónica Gudemos).

En un instrumento musical de este tipo es importante analizar las características internas del tubo. En este que estudiamos, la superficie habría sido pulida de tal modo que nos sorprendió el fino espesor de la pared ósea de la sección superior (la de mayor diámetro). Al introducir la sonda con cámara para observar posible manipulación y existencia de sustancias acumuladas en el desnivel de embutido de las secciones óseas (en caso de que haya sido un receptáculo), fue notable como se transparentó la luz de la cámara (véase Figura 3.3). Asimismo se constató que el interior del cuerpo tubular estaba completamente limpio. Es necesario comentar que, también, tuvimos en cuenta el hecho de que pudiera tratarse de un estuche de espinas de cactus para

6 Una embocadura sin canal de insuflación significa que no posee artificios constructivos para direccionar el aire del soplo contra un "filo de corte", como sí los tienen las flautas de pico. Esto es, que el músico debe tensar los labios para que el aire del soplo sea expulsado con la presión suficiente, en forma de cinta, contra el bisel de corte o borde de embocadura. Al "cortarse" esa corriente de aire contra el borde o filo del orificio de embocadura, parte del aire ingresará intermitentemente al interior del tubo, produciendo sonido musical. Cuando el aire se corta contra el borde del orificio de embocadura produce el característico "ruido a soplo" de estas flautas. 
la limpieza de tubos inhaladores, pero no se observaron marcas compatibles con ese uso. Tampoco se justificarían los cuidados constructivos (particularmente el sellado del extremo inferior) que, según nuestra opinión, sí se justifican con una funcionalidad acústica.

En lo que atañe al estudio musical y acústico propiamente dicho, la producción sonora de este tipo de flautas posee una textura de armónicos parecida a la de los tubos cerrados de las flautas pánicas de caña, construidos con dos secciones embutidas. Su "aspereza" tímbrica característica, no obstante, se aproxima a la del sonido de las pifilkas arqueológicas de igual taxón, procedentes de Chile (Grebe 1974; Gudemos 1998a; Pérez de Arce 2007). Ahora bien, no obstante, ese acercamiento a las texturas sonoras mencionadas fue interesante comprobar, en este caso, el enriquecimiento sonoro que aportan tanto la morfología compleja del tubo (que le otorga ese sonido "friccionado" o "rajado"; Pérez de Arce 2007: 221), como las variantes de la "sonoridad del hueso" a medida que éste adquiere temperatura (Figuras 5 y 6 ).

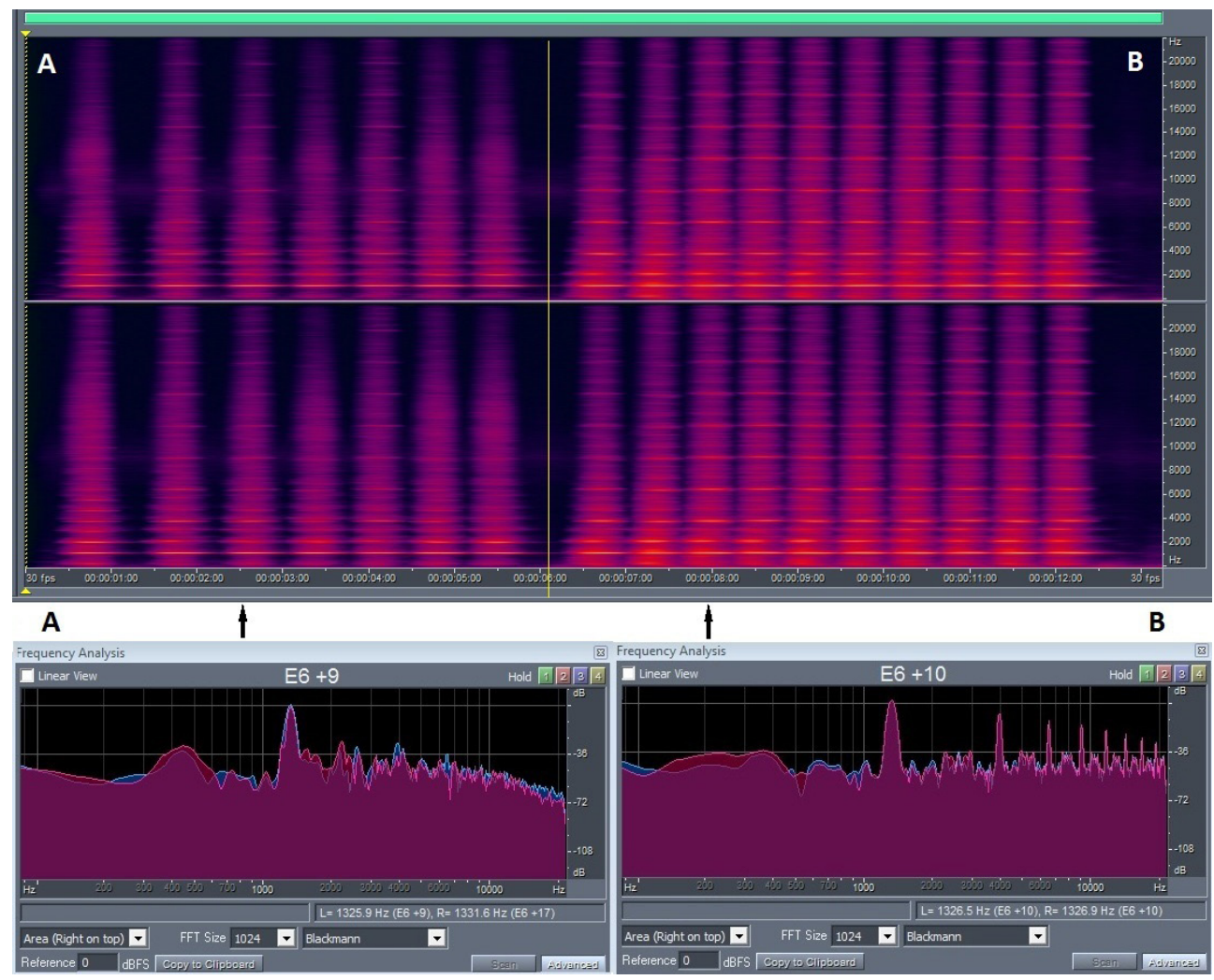

Figura 5. Gráficos espectrales de los sonidos producidos con una de las réplicas óseas realizadas ad hoc (véase Figuras 7 y 8), con incidencia directa de la corriente del aire del soplo contra el borde de la embocadura: arriba A) sonidos con armónicos poco definidos; arriba B) sonidos con mejor definición de armónicos; abajo A) análisis frecuencial del sonido capturado donde marca la flecha; abajo B) análisis frecuencial del sonido capturado donde marca la flecha. Obsérvese en este último gráfico la clara individualización de cada uno de los armónicos sobresalientes del sonido capturado (análisis y edición de Mónica Gudemos). 


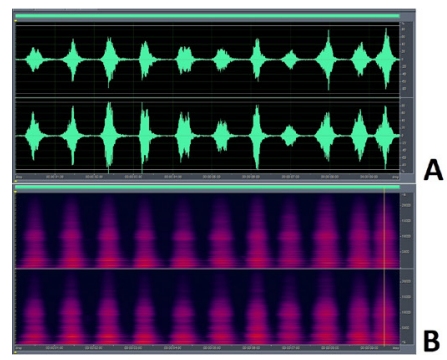

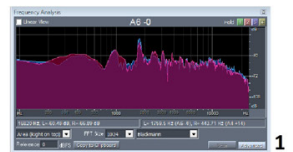

A

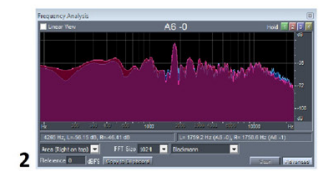

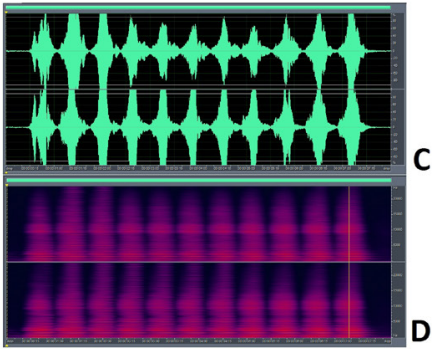

Figura 6. Gráficos espectrales de los sonidos producido con una de las réplicas óseas realizadas ad hoc (véase Figuras 7 y 8), sin incidencia directa de la corriente del aire del soplo contra el borde de embocadura (soplo "lleno"): A y B) sonidos producidos con intensidad moderada, con armónicos bien definidos, especialmente en sus componente graves; C y D) sonidos producidos con mayor intensidad y ataque brusco, con armónicos bien definidos; 1) frecuencia obtenida del sonido capturado en la línea amarilla que atraviesa verticalmente el último registro del gráfico B; 2) frecuencia del sonido capturado donde marca la línea amarilla en D. Obsérvese en D la mayor densidad textural de los sonidos y su enriquecimiento de componentes agudas (análisis y edición de Mónica Gudemos).

En nuestro trabajo no emitimos sonido con las flautas óseas originales. En laboratorio experimentamos con el sonido de réplicas modernas realizadas por nosotras con diferentes materiales ${ }^{7}$. Analizamos: 1) las variantes existentes entre la sonoridad de una caña ósea entera de diámetro naturalmente regular (como una pifilka simple; Grebe 1974; Pérez de Arce 2007), con respecto a la de una caña ósea de dos secciones embutidas de diferente diámetro (como la flauta del Museo de América que aquí analizamos); 2) la diferencia que existe entre la sonoridad de un tubo bi-diametral de cerámica, otro de piedra y uno de hueso. No experimentamos con réplicas hechas en madera.

En el primer caso pudimos obtener, por un lado, un sonido musical nítido correspondiente a la frecuencia fundamental de la longitud del tubo, al que se sumó la sonoridad "áspera" del ruido propio del corte del soplo contra el borde de la embocadura. Al jugar con distintas intensidades y ritmos de soplo se produjeron los característicos enrarecimientos frecuenciales. Por el otro lado, al tañer la flauta ósea bi-diametral (Figuras 7 y 8$)^{8}$, la fricción del aire contra el extremo embutido del hueso de menor diámetro generó una perturbación constante en el interior de la flauta que, irregularmente, fue produciendo bandas enrarecidas de armónicos. A esta fricción se sumó la propia del corte del aire del soplo contra el borde de la embocadura. En términos ge-

\footnotetext{
Por razones de espacio no presentamos aquí el proceso completo de producción de réplicas y análisis acústicos. Sólo nos centramos en aspectos pertinentes que ilustran dicho proceso con respecto a una de las réplicas óseas.

8 Nuestro interés en este estudio fue construir réplicas acústicamente semejantes a los aerófonos originales para realizar los análisis de su sonoridad, por eso trabajamos principalmente en la confección de los tubos acústicos, sin aplicarnos, por ejemplo, a los embobinados de tripa y/o tendón que, por otra parte, no siempre se encuentran a nuestra disposición en estado fresco para replicar el proceso constructivo original. Con respecto a los huesos utilizados en la construcción de réplicas, tuvimos en cuenta no sólo las secciones óseas identificadas en los aerófonos completos aquí analizados, sino también en los posibles fragmentos y secciones sueltas de estos aerófonos analizados por nosotras en la misma región (Gudemos 1998a, 2009, 2018). Dichas secciones corresponden en su mayoría a diáfisis de tibia, fémur, húmero y metapodios de camélido y de cérvido. Sólo tuvimos la posibilidad de trabajar con huesos secos, lo que fue, por cierto, considerablemente más difícil.
} 


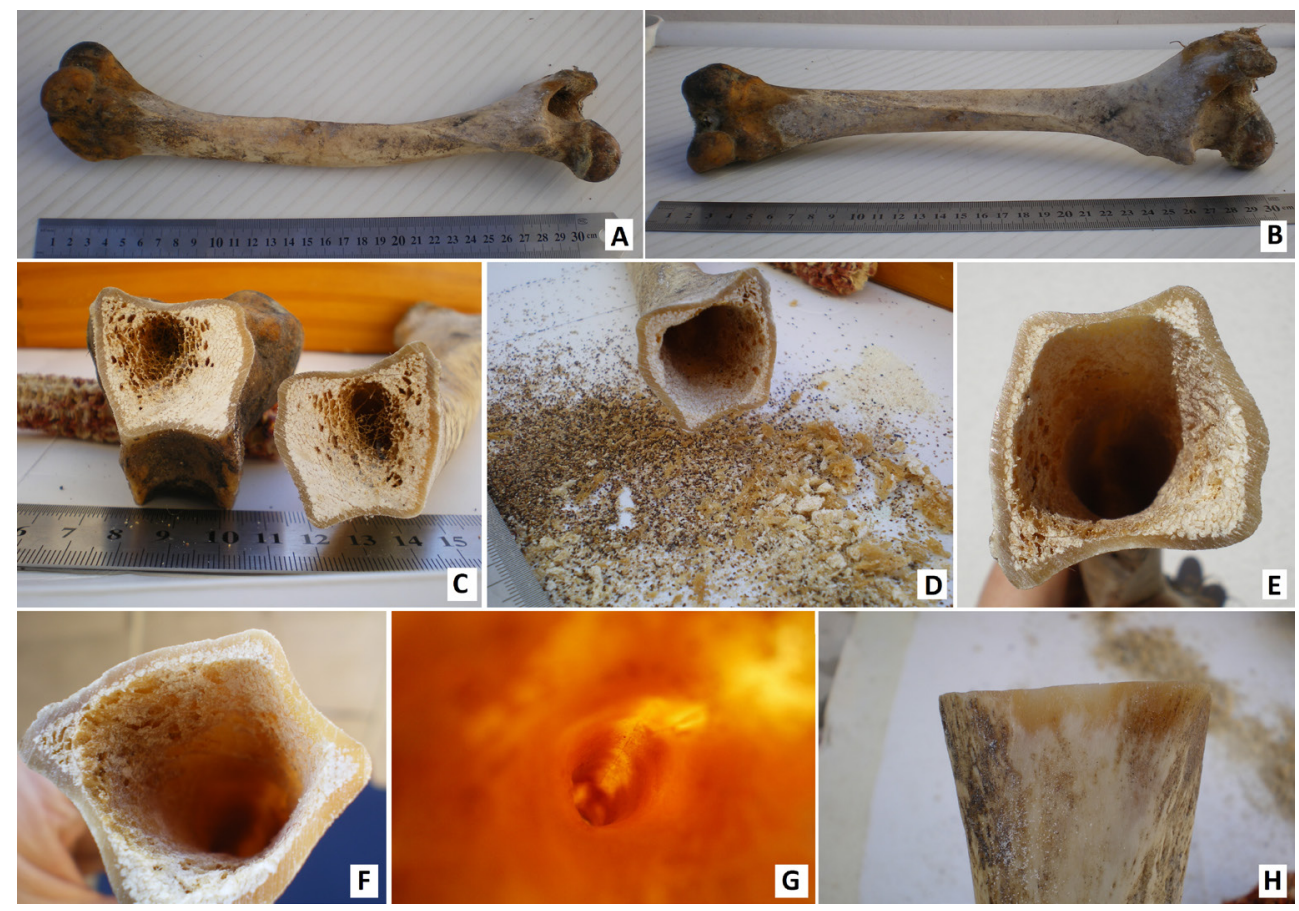

Figura 7. Construcción de la parte inferior de un aerófono bi-diametral como el que estudiamos a partir de una caña de fémur de camélido (Lama glama de porte mediano): A y B) fémur; C) vista del hueso en la sección de corte; D) preparación de la caña ósea como tubo acústico de aerófono, desbastado; E) extremo desbastado de la caña ósea; F) extremo pulido de la caña; G) vista del interior pulido de la caña ósea; H) extremo pulido de la caña que será ensamblado con la parte superior o boquilla (construcción y fotografías de Mónica Gudemos).

nerales percibimos una sonoridad densa, característica, poco nítida, en la que el ruido del tañido ("toma de aire" y soplo) se sumó al ruido friccionado de los cortes del aire en movimiento contra los diferentes perfiles y al sonido musical propiamente dicho. Todo lo cual, de acuerdo a la intensidad y el ritmo del soplo, provocó un extraño "enmascaramiento" de tesituras graves y agudas. Pensamos que tales "rugosidades" del sonido, fueron específicamente buscadas por los músicos constructores de este tipo de aerófonos, respondiendo tal vez a un rasgo característico de la estética sonora de su contexto cultural. A medida que el hueso se fue calentando y humedeciendo por la acción del tañido, dicho enmascaramiento fue disminuyendo, estabilizándose con mayor nitidez la producción de armónicos (véase Figura 5.B). También experimentamos con el tañido por soplo "lleno", esto es, sin que la corriente del aire del soplo incida para su "corte" directamente sobre el borde de embocadura, sino dirigiéndola con fuerza en forma de cinta hacia el interior del tubo acústico, obteniendo una interesante producción de armónicos, dependiendo ésta de las diferentes intensidades del soplo. En ese juego de dinámicas sonoras se aprecia auditivamente una coexistencia frecuencial que enriquece notablemente la textura del sonido (véase Figura 6). 


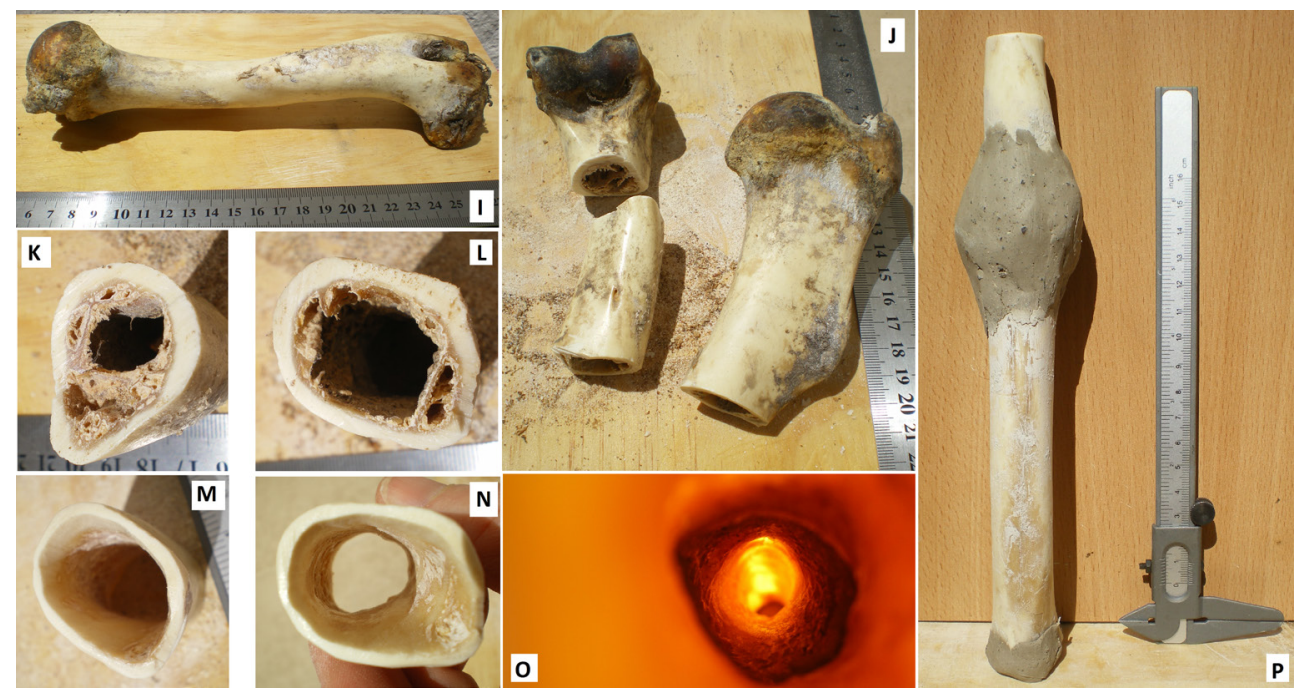

Figura 8. Construcción de la parte superior o "boquilla" de un aerófono bi-diametral como el que estudiamos a partir de una caña de húmero de camélido (Lama glama de porte mediano): I) húmero; J) sección de caña; K y L) vista de la caña en ambas secciones de corte; $\mathrm{M}$ y N) vista de los extremos pulidos de la caña ya desbastada; O) vista del interior del tubo acústico de la flauta con las dos partes ensambladas; P) vista externa de la réplica construida (construcción y fotografías de Mónica Gudemos).

\subsection{Flauta de hueso de Doncellas, Puna de Jujuy, Argentina}

El tipo de unión así como los materiales empleados en su fabricación nos remitieron directamente a otros ejemplares de diferente taxonomía, procedentes de regiones transcordilleranas analizados anteriormente (Gudemos 1998a, 2009, 2018). En algunos de ellos observamos secciones óseas acopladas y modos de ensamblaje semejantes a los del objeto que estudiamos. Lo notable es que, aun tratándose de otras organologías musicales e incluso de objetos con diferentes funciones, constatamos procedimientos constructivos semejantes. En este punto, debemos aquí rectificarnos con respecto a observaciones realizadas en anteriores publicaciones. En ellas considerábamos el objeto de las colecciones del Museo Dr. Eduardo Casanova identificado con el № 1609, procedente de Doncellas (1210-1677 d.C.; Fernández Distel 1997: 226), arriba mencionado, un receptáculo (véase Figura 4.2). Este objeto presenta semejantes dimensiones ( $220 \mathrm{~mm}$ de largo) y características constructivas a las del ejemplar procedente de Chiuchiu que aquí presentamos, incluyendo las tirillas de caña y el embobinado de fijación.

\subsection{Flauta de hueso de Salinas Grandes, La Poma, Provincia de Salta, Argentina}

En este punto debemos mencionar otra estrecha analogía con el tubo de Doncellas y el de Chiuchiu la cual ya había sido advertida por nosotras en un trabajo anterior (Gudemos 2009); en él se destacaba la similitud con el denominado "cetro" de hueso del ajuar funerario del niño sacrificado hallado en Salinas Grandes (Figura 9.1). Este 


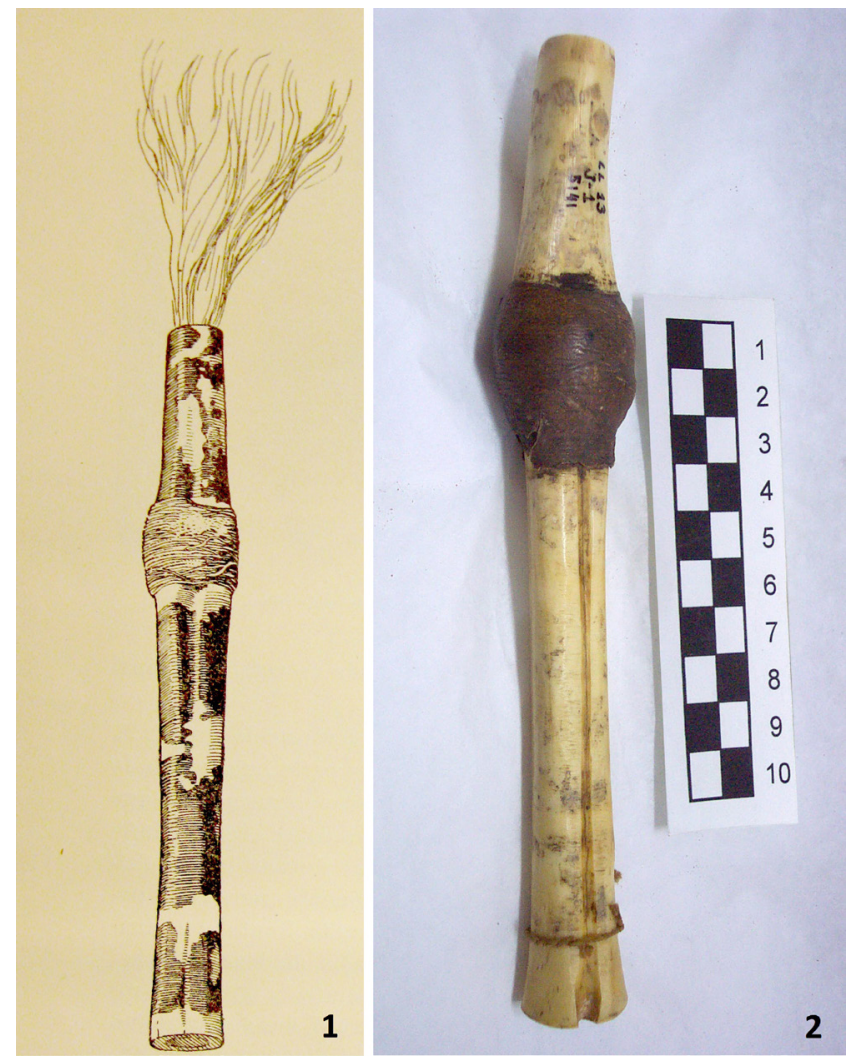

Figura 9. Flautas óseas bi-diametrales: 1) flauta del ajuar del niño sacrificado de Salinas Grandes, La Poma, Provincia de Salta, NOA, longitud= $260 \mathrm{~mm}$ (dibujo tomado de Boman 1918); 2) flauta $\mathrm{N}^{\circ} 5141$ (Col. Manuel Blanco Encalada), de la tumba J/1 de Lluta 13, Molle Pampa, Arica, norte de Chile (fotografía de Helena Horta).

supuesto "cetro" de $260 \mathrm{~mm}$ de largo se halló junto al infante de 6 años, al igual que una diadema de oro de forma muy especial cosida a un textil que debió rodear la frente, dos anillos de cobre idénticos en los dedos anulares y una pulsera de cobre en la muñeca (Boman 1918: 10; Besom 2010: 413), indicando claramente la condición de alto rango del niño ofrecido en el marco del rito incaico de la capacocha (Boman 1918; Besom 2009; Patané 2015). Con respecto a los huesos utilizados en la construcción de este "cetro", según Boman (1918: 10), se trataría de dos metacarpianos de Odocoileus antisensis D'Orbigny, o ciervo andino. Sin embargo, según la determinación realizada recientemente por el colega Boris Santander se trataría de metapodios de taruca (Hippocamelus antisensis D'Orbigny, 1834).

De acuerdo con el reporte de Boman, el cabello del niño se encontraba peinado en múltiples trencitas, detalle relevante si tomamos en consideración las evidencias de otros jóvenes ofrendados en capacochas del sur andino: tanto el niño del cerro El

9 Comunicación personal del 6 de febrero de 2021. 
Plomo como la "Doncella" del Llullaillaco exhibían el mismo tipo de arreglo del cabello (Mostny 1957; Reinhard y Ceruti 2000). Mostny considera indicador de filiación étnica altiplánica precisamente a dicho peinado, estableciendo una marcada diferencia respecto de la usanza incaica de pelo corto a la altura de las orejas en las representaciones de Guamán Poma (Mostny 1957: 33). Desafortunadamente, la vestimenta del infante de Salinas Grandes no se conservó, pero sí huellas de su color original: rojo púrpura (Boman 1918), cuestión que también apunta a su especial carácter de ofrenda. Besom propuso para él su calidad de colla en base a la vestimenta, peinado de trencitas y el ornamento de metal ya señalado, a los cuales considera en conjunto como rasgos propios de un "noble provincial del Collasuyu" (Besom 2010: 417). Además, resalta el hecho de que la vestimenta, ornamentos y peinado del niño coinciden con el atuendo de los funcionarios estatales del Collasuyu en las láminas de Guamán Poma, entre las cuales destaca: túnica, brazalete, colgante en forma de " $\mathrm{H}$ " (adorno de barbilla sensu Horta 2016), peinado y mocasines ${ }^{10}$ (Besom 2010: 417), a lo cual habría que agregar también el gorro troncocónico (Horta 2011a y b), tal como se aprecia en las láminas de Guamán Poma que veremos más adelante. En consecuencia, se trata de un conjunto de rasgos culturales que denotan a un grupo humano no inca.

\subsection{Flauta de hueso del valle de Lluta, Arica, Chile}

Una de nosotras ya había aportado información relevante para nuestro estudio al ofrecer detalles sobre los materiales excavados en la tumba $\mathrm{J} / 1$ de Lluta 13 (Molle Pampa, Arica, norte de Chile. Col. Manuel Blanco Encalada), considerada como lugar de entierro de un curaca de los mitimaes altiplánicos trasladados al valle de Lluta por la administración incaica a la luz del testimonio de sus bienes funerarios (Horta 2015: 317-319). En este mismo contexto se mencionaba un objeto de función desconocida (tubo de hueso 5141), pero sobre el cual se descartó su condición de instrumento musical luego de haber consultado a un especialista ${ }^{11}$. Tal como se aprecia en la Figura 9.2, se trata de un instrumento compuesto por dos diferentes huesos de camélidos huecos y unidos por medio de resina, cuya parte superior presenta una leve curvatura. En su momento, por semejanza con un ejemplar exhibido en el Museo Etnográfico J. B. Ambrosetti se acogió la función que se le asignaba en dicho museo (parte del "equipo para inhalar cebil"), aunque la duda persistía debido al grosor del hueso, el que resultaba inusual para constituir un tubo de inhalación (Horta 2015: 319). Por un lado, podemos considerar que, después del análisis del ejemplar de Chiuchiu y el de Doncellas (semejantes en su estructura funcional), y por las mismas previsiones planteadas por Horta al observar que le sorprendía el grosor del instrumento, el objeto del contexto $\mathrm{J} / 1$ ahora puede ser verificado como instrumento musical. Si nuestra propuesta es correcta, el hecho de que haya pertenecido a un varón adulto es ampliamente significativo para nosotras en su relación simbólica con la Fiesta de los Collasuyus y el Entierro de Collasuyus que registra Guamán Poma, tal como se verá más adelante. Por otro lado, resulta igualmente relevante que este

10 El uso de mocasines también se registra en Guamán Poma en relación con personajes del Contisuyu, pero no así para los otros dos suyus (véase Láminas 171 [173], 295 [297]; Guamán Poma 1980: 122, 210).

11 Horta consultó al respecto al etnomusicólogo J. Pérez de Arce, para quien este tubo resultó desconocido, descartando que se tratase de una flauta (Horta 2015: 319). Por cierto, cabe aclarar que Pérez de Arce sólo revisó fotografías del objeto, no el objeto propiamente dicho. 
objeto se haya encontrado en un contexto material relacionado con dos individuos (masculino y femenino) de alto rango, trasladados -según la propuesta de Hortacomo mitimaes altiplánicos al valle de Lluta por la administración incaica, por lo que se trataría de un objeto cultural de ascendencia altiplánica en el norte de Chile (Horta 2015: 317). Esta observación es también importante en nuestro estudio respecto del contexto social del objeto. Como veremos más adelante, si el varón adulto fuese un curaca de tales mitimaes, esto permitiría pensar que se trataría de un objeto vinculado a la parafernalia del poder o de uso exclusivo de personajes de elite. Ahora bien, Molle Pampa dista bastante hacia el norte de la región del río Loa. No obstante, en ambos lugares se habrían hallado estos objetos de hueso que estudiamos. Asimismo, en Lluta 13, la presencia de gorros troncocónicos en técnica de aduja sin diseño estandarizado (Horta 2015: 164-165) nos informaría sobre la presencia de mitimaes altiplánicos de filiación Pacaje, principalmente entre 1400-1536 d.C. (Horta 2015: $388,395)$. Respecto a este tipo de gorros, hemos señalado en relación con su radio de difusión que los lugares de aparición más distantes en el Norte Grande de Chile se encuentran aisladamente en la región del río Loa: en Quillagua (dos ejemplares del cementerio poniente, ambos con fiador; Latcham 1938) y en Topater (pieza 573, Museo de El Loa; Horta 2015: 252). Latcham describe así los gorros hallados en Quillagua: "Estos dos tenían forma de gorro turco de aquellos llamados fez. Eran hermosamente decorados en colores, con dibujos geométricos" (Latcham 1938: 287). De acuerdo con esta descripción, podemos deducir que igualmente se trata de gorros troncocónicos en técnica de aduja, pero con diseño estandarizado: tipología de tocados que denotaría también la presencia en Quillagua de mitimaes altiplánicos, en este caso de presumible filiación Caranga (Horta 2015: 388). Estos datos apoyan la hipótesis más general que planteáramos en su momento acerca de la identificación étnica por medio del uso de tocados específicos, y otra más circunscrita al uso diferencial de éstos al interior de los señoríos altiplánicos (Horta 2011a: 574).

\section{La comunicación visual de Guamán Poma}

Al analizar el objeto hallado en Chiuchiu y reconsiderar los procedentes de Doncellas y Lluta 13, respectivamente, nos vimos instadas a revisar las argumentaciones que habíamos emitido previamente. En efecto, al considerar comparativamente estos objetos pensamos en la existencia de una taxonomía instrumental semejante a la que Guamán Poma dibujó en dos importantes contextos que aluden a ritos de la población altiplánica: la Fiesta de los Collasuyus ${ }^{12}$ y el Entierro de Collasuyus ${ }^{13}$ (láminas 324 [326] y 293 [295]; 1980: 232, 208; aquí Figuras 10 y 11, respectivamente). La notable elocuencia con la que el cronista registró el instrumento musical tañido por el grupo de hombres participantes en la Fiesta, y el sostenido en una mano por el difunto de alto rango en el Entierro, nos permite realizar observaciones organológicas de pertinencia como para argumentar su relación con los objetos arqueológi-

12325 [327] "La fiesta de los Colla Suyos desde el Cuzco cantan y danzan....desde Cavina, Quispi Llacta, Poma Canchi, Cana, Pacaxi, Charca, Choquiuito, Chuquiyapo y todo Hatun Colla, Uro Colla" (Guamán Poma 1980: 209)

13294 [296] " [...] Y en los cinco les entier[r]an asentado con mucha bestidura y baxillas de oro y de plata y de barro [...] Y ací le entierran con sus comidas y ueuidas y cienpre tienen cuydado de enbialles de comer y de ueuer" (Guamán Poma 1980: 234) 


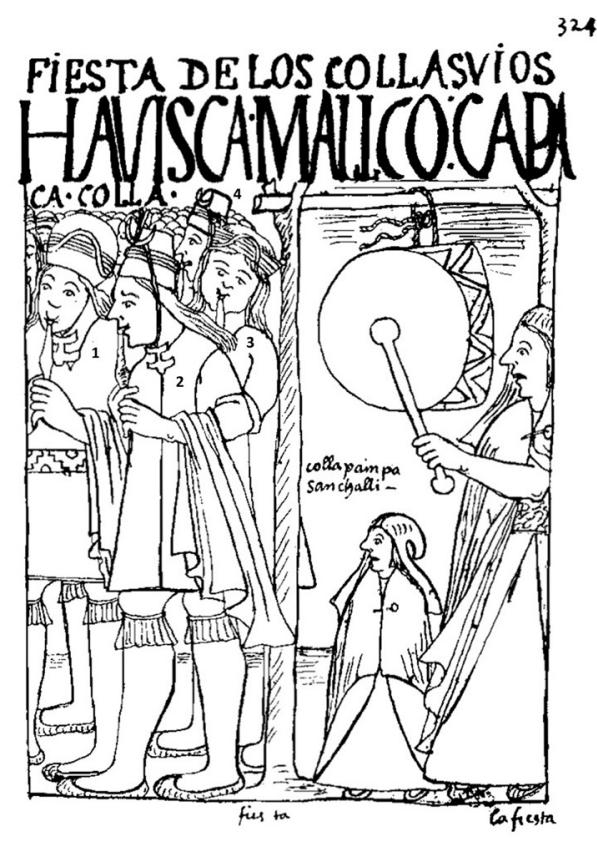

Fiesta de los Collasuyus / Hauisca Malleo Capaca Colla / Collapampa / Sanchalli, A

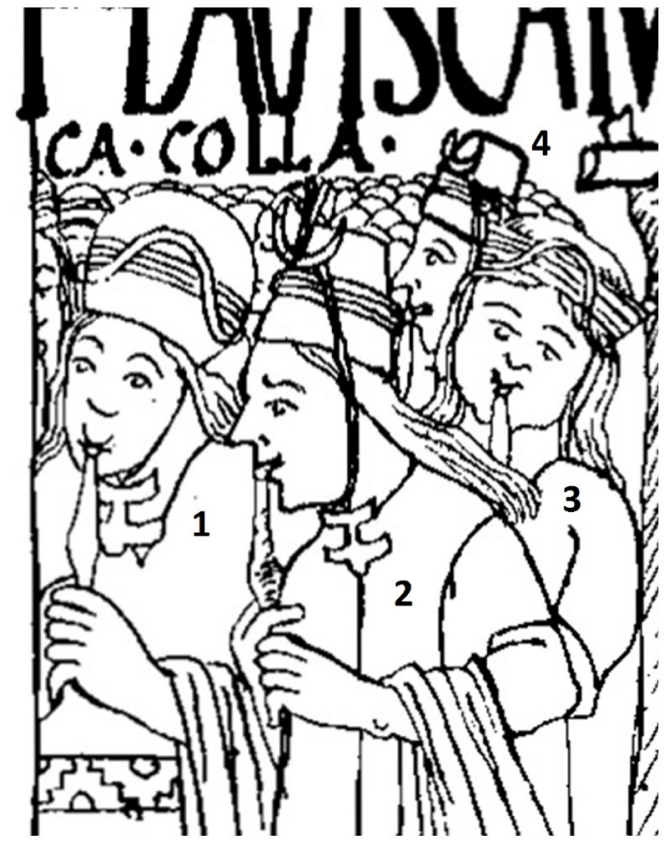

B

Figura 10. A) Fiesta de los Collasuyus; B) Detalle de músicos (lámina 324; Guamán Poma 1980: 232)

cos mencionados, incluso en lo referente a las estrategias constructivas. Obsérvese cómo en el instrumento que aparece dibujado en ambos casos pueden distinguirse las líneas que aludirían al embobinado, así como el abultamiento en el perfil del mismo que representa la unión de los dos huesos debido a la cerámica y/o resina aglomerada en ese sector. Aunque contamos con la elocuencia de las imágenes de Guamán Poma, es escasa la información que encontramos en las fuentes primarias y secundarias sobre la tipología de flautas que estudiamos. En primer lugar tenemos que argumentar la razón por la cual consideramos que lo que Guamán Poma registra plásticamente en su dibujo son aerófonos de soplo, específicamente flautas tubulares, longitudinales. Esto es, flautas que se soplan por una abertura ubicada en uno de los extremos del cuerpo tubular, pudiendo tener obturado o no el extremo opuesto al de la embocadura. Al respecto, la información gráfica del cronista posee una validez técnicamente pertinente a nuestro interés, puesto que no quedan dudas acerca de que lo que dibuja en la lámina 324 es una flauta del tipo arriba descrito (véase Figura 10). Él conocía perfectamente lo que era una flauta de pico con canal de insuflación, como la que tañen los soldados españoles por él dibujados en las láminas 44 [44] y 371 [373] (Guamán Poma 1980: 36, 261), y una flauta sin pico ( $\sin$ canal de insuflación), de embocadura sin muesca como la de los Collasuyus. Incluso, conocía la diferencia entre una flauta de pico y una flauta del tipo quena (flauta longitudinal, abierta por ambos extremos, sin canal de insuflación, embocadura con muesca y tubo con orificios para el cambio de tono), puesto que lo puso 


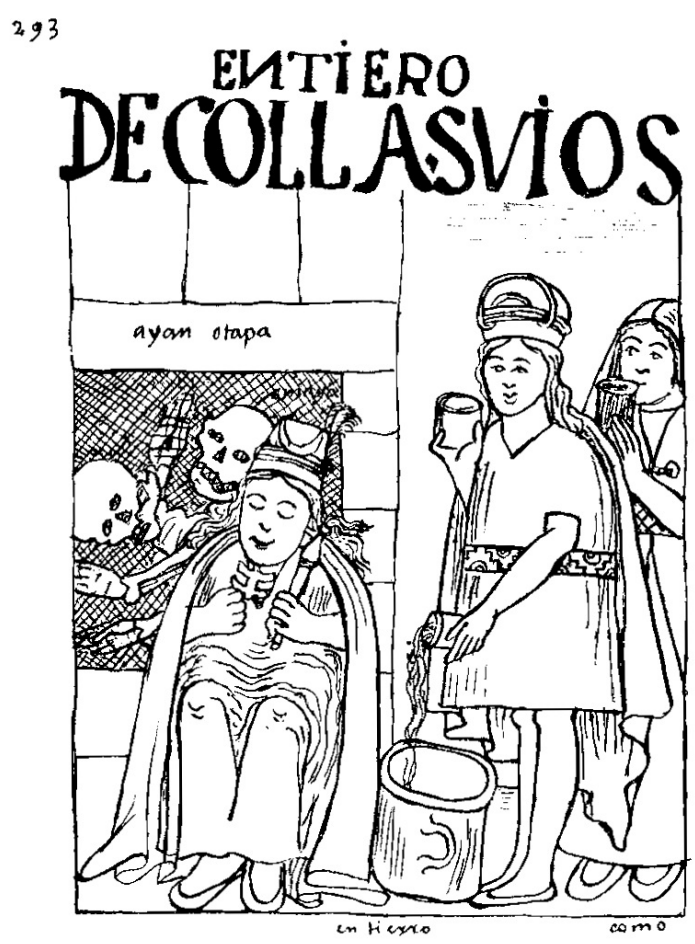

Figura 11. Entierro de Collasuyus (lámina 295; Guamán Poma 1980: 208)

de manifiesto en el dibujo de la lámina 316 [318] que mostramos en la Figura 12 (Guamán Poma 1980: 225). En su discurso visual Guamán Poma dibuja en esta lámina una flauta de pico (el pico en punta está entre los labios del joven señalado con el número 1 en la Figura 12 B) y una flauta del tipo quena. En este último caso la embocadura sin punta está situada debajo de los labios del joven señalado en la misma figura con el número 2, tal como se requiere para el tañido de este tipo de flautas sin canal de insuflación con muesca. En la lámina 324 (véase Figura 10) el autor registra con la más clara objetividad el tañido concertado de un aerófono que no sólo habría presenciado "en vivo y en directo", sino que es muy posible que lo haya tañido él mismo. Sólo así se explicaría la estrategia "pedagógica" de mostrar desde diferentes ángulos la posición de los labios de los músicos sobre una embocadura circular, sin escotadura o muesca. El músico señalado con el número 1 en la Figura 10.B fue registrado tensando el labio superior en correcto ángulo de soplo sobre el orificio de embocadura, pero aún sin insuflar (sus mejillas están planas). No deja dudas de que el labio inferior está detrás, plano y oprimido por el extremo superior de la flauta. En la misma figura, el músico 2 fue registrado en pleno toque, de perfil. Se observa claramente la posición de los labios con respecto al borde circular de la embocadura en el momento de insuflación (nótese cómo el autor ha marcado la forma abultada del cuello debajo de la barbilla, en tensión con la presión de la cuerda que sujeta su chucu o gorro troncocónico). El músico 3 también se registró insuflando, pero de frente, con las mejillas abultadas y los labios tensados en posición de insuflación. El músico 4, por su parte, está aspirando aire sin perder la 


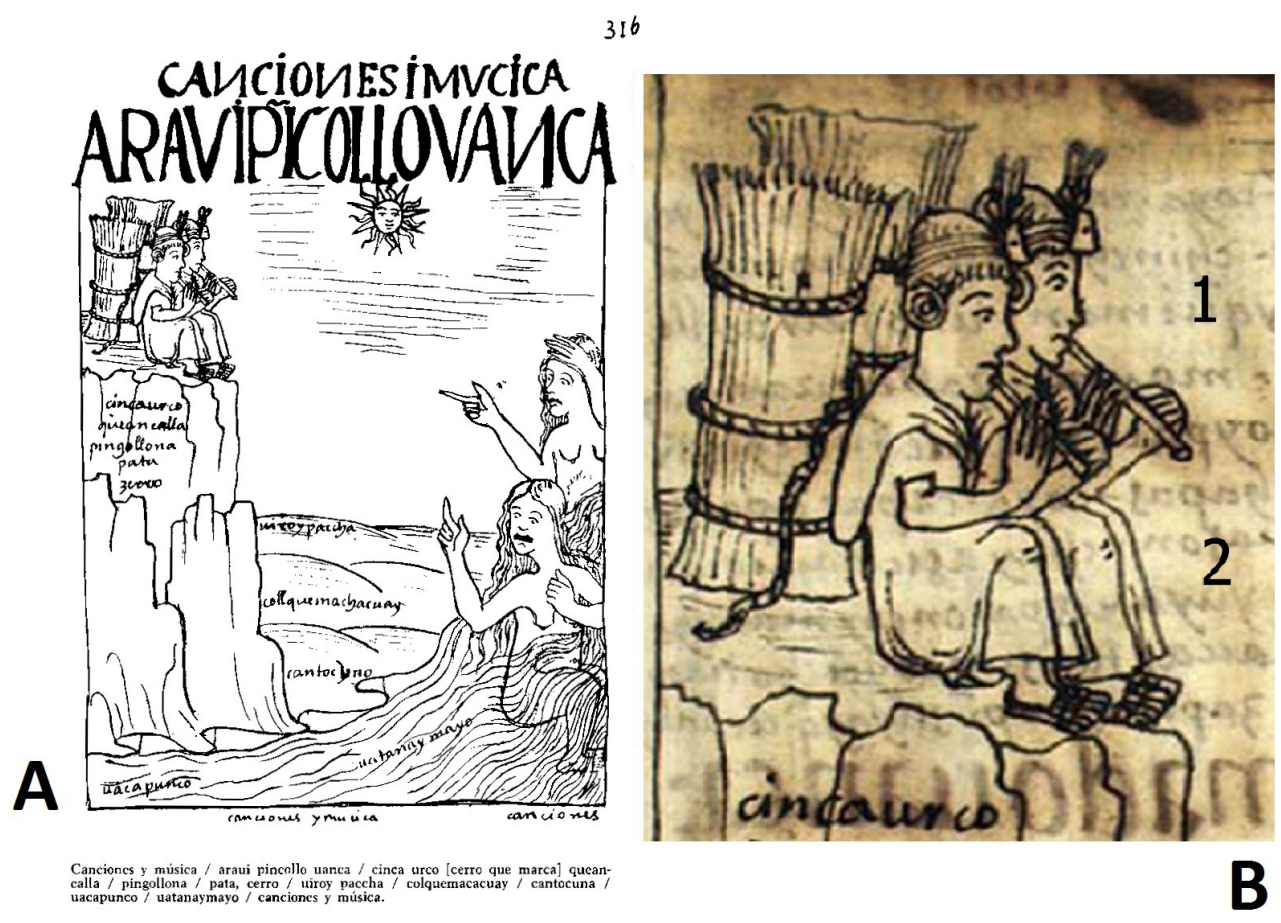

Figura 12. A) Canciones y Música (lámina 316; Guamán Poma 1980: 225); B) detalle de músicos (lámina 316 [318]; Guamán Poma 1615).

posición tensada de los labios, de allí la ligera abertura de las comisuras. En la jerga musical, "tomar aire" sin perder la posición de los labios, podría significar que se está tañendo a ritmo marcado y, posiblemente, con ataques de soplo de cierta intensidad. Tales detalles sólo se individualizan en la observación atenta y se registran cuando se tiene conocimiento técnico de ellos, más precisamente cuando se cuenta con la experiencia física del tañido de este tipo de aerófonos.

Ahora bien, si tenemos en cuenta lo arriba observado con respecto a que dos músicos (2 y 3, respectivamente, en la Figura 10 B) se encontrarían en el momento mismo de la insuflación propiamente dicha y que los otros dos ( 1 y 4 ) no (puesto que uno está aspirando y el otro con los labios en posición pero sin la tensión de insuflación que muestra el músico 3), podríamos argumentar que se trata de un tañido por pares alternados, muy difundido en las tradiciones musicales andinas. El toque de tambor marcaría el tempo, dando el sustento temporal de la base rítmica de coordinación de los toques de flautas y de "avance", en el caso que, efectivamente, fuese una performance procesional. Puede, sin embargo, tratarse de individuos tañendo colectivamente en forma coordinada al son del tambor percutido por mujeres, respirando cada uno "a su tiempo". No obstante, la gestualidad corporal de los músicos 1 y 2 entre sí, acusaría una coordinación concertada y alternada de a pares.

Por otra parte, resulta sumamente interesante observar la estrategia del autor en el manejo de los planos performáticos. Su mirada de registro se posiciona en proximidad a un primer plano, de tal manera que el volumen de los cuerpos de los músicos 
mencionados no nos permite ver detrás de ellos, pero sí saber que son parte de una multitud en movimiento captada en una instantánea gráfica (véase Figura 10 A). Una multitud que parece dirigirse en giro procesional hacia nuestra izquierda (véase la posición de los pies), agolpándose contra el marco de la imagen que limita nuestra visión de la acción. No obstante, por esa estrategia que consideramos, como dijimos, "pedagógica", es que el autor sabe que debe darle al lector información suficiente, para que no queden dudas de que esa multitud se encuentra socializada participativamente en el mismo evento sonoro y que cada individuo masculino que la conforma tañe el mismo instrumento musical, tal como magistralmente lo dibuja con pocos trazos en el conglomerado agolpado a nuestra izquierda. Por las insignias de media luna que llevan en la frente y los tocados masculinos (chucu redondo o hemisférico y chucu troncocónico) podemos inferir que quienes tañen flauta son dignatarios del Collasuyu (Horta 2015: 281).

\section{La interpretación cultural de la evidencia arqueológica en el contexto sonoro}

Bertonio (1612, II Parte, folio 266) registra en su Vocabulario de la Lengua Aymara el término pincollo para "flauta de huesso de que vsan los indios, y tambien estotras que traen de castilla". Con ello y en primera instancia, nos informaría sobre dos categorías básicas: las de hueso que usan los indios y otras que traen de Castilla, pero no nos permite inferir si ambas categorías poseen aspectos organológicos específicos, como para conjeturar si son flautas de pico o sin él, o si las que traen de Castilla son de otro material, por ejemplo. Entonces, con el término pincollo podría comprenderse en aimara tanto las flautas de hueso "que usan los indios", esto es, que pertenecen a la categoría jurídica colonial "indio", como "estotras" que traen de Castilla, diferentes o no organológicamente.

Ahora bien, también es posible que con "estotras que traen de castilla", Bertonio hiciera referencia a que no sólo se llamaba pincollo a las flautas de hueso, sino también a las flautas (de tradición europea o no) construidas con caña braua "assi como la de castilla" (Bertonio 1612, I Parte, folio 115); es decir, aquellas construidas con una "caña más gruesa que las de españa, de la misma color" llamada tocora tupa (Bertonio 1612, II Parte, folio 357). Seguidamente, cuando registra el término pincollori para músico "porque de ordinario tañe también flauta", Bertonio especifica que cchaca pincollo es una flauta de hueso, mientras que quinaquina pincollo es una flauta de caña (Bertonio 1612, II Parte, folio 266). Lo interesante de esta especificación es que podría estar indicando, además de una materialidad diferente, una tipología organológica precisa. En efecto, qena quena pincollo no sólo sería una flauta de caña (Bertonio 1612, II Parte, folio 289), sino también una flauta con agujeros para el cambio de tono, puesto que quena quena es una "cosa muy agugereada" (Bertonio 1612, II Parte, folio 288); siendo quena quenachatha el verbo correspondiente a la acción de "agugerear haciendo muchos agugeros" (Bertonio 1612, I Parte, folio 29). Por lo pronto, podríamos conjeturar que cchaca pincollo, además de ser una flauta de hueso, no tendría agujeros, puesto que si los tuviera (como "cosa agugereada") habría sido identificada como tal. Gonçález Holguín, a su vez, registró en su Vocabvlario de la lengua Qquichua el término pincullu como "todo género de flautas" (Gonçález Holguín 2007: 193), sin mayores especificaciones. Siglos más tarde, Jorge Lira en su Diccionario Kkechuwa-Español de 1944 registra para pinkúyllu 
y otros pinkíllo y pinkíyllu "pífano, flautín, flauta. Instrumento de viento que lleva contralto, fabricado a imitación del pífano, excepto la quena" (Lira 1944: 754). Más allá de las especificidades de pertinencia organológico-musical, lo interesante en esta referencia es que con el término pinkúllu se aludiría a flautas, "excepto la quena". ¿Por qué esa diferenciación tan expresa?, ¿tal vez porque da por entendido que el lector conoce aspectos técnicos específicos, como que la quena es longitudinal (con la embocadura en un extremo del tubo) y que las otras son traveseras?, por ejemplo; es decir, ¿porque considera pinkillo sólo las flautas de ascendencia cultural europea "fabricadas a imitación del pífano" y no la quena, propiamente indígena?

Profundizando con respecto a las expresiones musicales masculinas, si observamos el dibujo de Guamán Poma correspondiente a la Fiesta de los Collasuyus (véase Figura 10) no es la quena el instrumento musical tañido por los hombres. La quena estaría representada, como dijimos, en el pincollo tañido por el mozo señalado con el número 2, del dibujo registrado por el cronista en la lámina 316 correspondiente a Canciones y Música (Figura 12 B). En efecto, en esta imagen está registrado el modo en que el mozo dispone ambas manos en una clara acción de utilizar los dedos para obturar o liberar los orificios de digitación para el cambio de tono; diferente disposición a la que utilizan los hombres para sujetar sus aerófonos en la imagen correspondiente a la Fiesta de los Collasuyus. Aerófonos que se registran gráficamente en forma vertical, paralela a la línea corporal, mientras que las flautas de la lámina 316 se registran elevadas diagonalmente. Esta disposición de los aerófonos no es carente de sentido, todo lo contrario, responde a una exigencia de ubicación de los labios para lograr un mejor direccionamiento de la corriente de aire del soplo contra el filo de corte de la embocadura, según tenga muesca o no la tenga. Los aerófonos longitudinales sin canal de insuflación con muesca (hendidura biselada en forma de "V" o "U" practicada en el borde de embocadura), como la quena, requieren esa inclinación apartada del cuerpo que Guamán Poma registra en la lámina 316, más aún cuando se "juega con los dedos" para los cambios de tono. Argumentación esta última que iría en favor de que la partecita faltante del borde de embocadura en la flauta del Museo de América que estudiamos es una pérdida de material y no una muesca. En consecuencia, la disposición de los aerófonos tubulares de los Collasuyus nos indicaría que se trata de aerófonos longitudinales sin canal de insuflación, esto es con un borde de embocadura simple, regularmente biselado en parte o totalmente, para el corte de la corriente del aire del soplo, y sin agujeros. También es importante destacar que los mozos de la Figura 12 participan de una ceremonia de la elite cusqueña, de acuerdo con el testimonio de las insignias trapezoidales (canipu) que portan en la frente junto a un penacho de dos plumas, así como las orejeras y sandalias; estos últimos, como elementos de la vestimenta de alto rango, y las primeras como insignias exclusivas de los miembros del Capac ayllu (Horta 2008). En el Entierro (véase Figura 11) se aprecia el rito funerario altiplánico, mientras se desarrolla una libación en vasos tipo quero de parte de los deudos. El difunto permanece sentado, vestido y engalanado con todos los atuendos ya mencionados, que denotan su rango (entre ellos el más conspicuo, el adorno de barbilla; Horta 2016). De acuerdo con nuestro análisis, portaría en una mano la flauta tubular en cuestión, de la cual asomaría un copo de fibra de camélido, al igual que la flauta considerada "cetro" del infante de Salinas Grandes. En relación con la función de cetro sostenida por Boman (1918), es necesario precisar que en el registro arqueológico conocido para el sur andino no figuran objetos que pudiesen ser clasificados de acuerdo a dicha función, situación 
que refuerza nuestra propuesta de que se trataría de un instrumento musical. Un aerófono que posiblemente, por sus cualidades denotativas, tenía que ser "enmudecido" al fallecer quien le insuflaba la vida del sonido, introduciendo en su interior vellones de lana.

Teniendo en cuenta todo lo dicho, la Fiesta de los Collasuyus sería una ceremonia de elite que implicaba el uso de la flauta tubular junto con grandes membranófonos suspendidos en estructuras ad hoc. Tal como hemos visto, en el caso del Entierro, se trataría de la ceremonia fúnebre de un individuo de alto rango, quien es enterrado con sus bienes más preciados, entre los que se encontraría una flauta tubular. En este punto, hay que destacar el vínculo conceptual y ritual que se puede apreciar entre esta flauta y aquella que acompañaba al niño de Salinas Grandes, dotándolo de rango e identidad en el marco especial de una capacocha. Entonces, podríamos concluir parcialmente, diciendo que el aerófono registrado gráficamente por el cronista en ambas láminas es una flauta longitudinal, sin canal de insuflación, sin agujeros para el cambio de tono y, posiblemente, de hueso. A ello podemos agregar que los detalles de su diseño son semejantes a los de los ejemplares arqueológicos que hemos analizado (Chiuchiu, Doncellas, Lluta, Salinas Grandes); que habría sido un instrumento musical socialmente masculino y de tañido colectivo por el grupo de elite en ceremonias y ritos locales reconocidos por la administración incaica; que su performance sonora (posiblemente coordinada de a pares) estaba complementada con la sonoridad de grandes tambores suspendidos en travesaños de madera, y cantos colectivos femeninos, así como con la gestualidad coreográfica de un desplazamiento igualmente colectivo, en el marco de una celebración del calendario ritual, en la cual había danzas y cantos ceremoniales ${ }^{14}$.

\section{Conclusión. El sonido de la ofrenda a los mallkus}

Es posible, entonces, que el instrumento procedente de Chiuchiu sea un elemento foráneo y que la tradición constructiva que observábamos como propia de Quebrada de Humahuaca y Puna (Gudemos 2009) sea la asimilación local de una tecnología "importada". Por lo pronto y con los datos que tenemos hasta ahora, podríamos pensar en una particular tipología de aerófonos de ascendencia cultural altiplánica inserta en una interesante dinámica interregional con la región del río Loa en el norte de Chile y con la región de Puna en el NOA. El análisis iconográfico que hemos llevado a cabo en este trabajo permite agregar un elemento nuevo a la lista de objetos que caracterizan las representaciones de dignatarios altiplánicos en las crónicas visuales de tiempos coloniales tempranos (Guamán Poma y Murúa 2004); así es como junto con el tipo de túnica con faja en la cintura, mocasines de cuero, gorros troncocónico y hemisférico envueltos en ocasiones por el llautu, pelo largo suelto o en trenzas, insignia en forma de medialuna para la frente y el adorno de barbilla, podemos actualmente considerar también a la flauta longitudinal bi-diametral como parte de los rasgos culturales que denotaban la filiación altiplánica. Todo ello en clara contrapo-

14315 [317]. CAPÍTVLO PRIMERO DE LAS FIESTAS, PASQVAS y dansas taquies de los Yngas y de capac apoconas [señores poderosos] y prencipales y de los yndios comunes destos rreynos, de los Chinchay Suyos, Ande Suyos, Colla Suyos, Conde Suyos. Los quales dansas y arauis [canción] no tiene cosa de hechisería ni ydúlatras ni encantamiento, cino todo huelgo y fiesta, rregocixo. (Guamán Poma 1980 [1615]: 226) 
sición con la vestimenta y atuendos de los nobles incas cusqueños, quienes son retratados por los cronistas mencionados con túnicas de tapicería y labores de tocapu, ojotas de fibra de camélido o vegetal, llautu, casco para contexto bélico, pelo corto a la altura de las orejas, insignias metálicas canipu y tincurpa (Horta 2008), a lo cual hay que agregar la flauta tipo quena.

Un instrumento musical y su sonido, un documento y las semióticas no verbales de una intención pedagógica, una expresión sonora colectiva y la demarcación del escenario territorial en el que dicha expresión cobraba sentido social. Todo formando parte del discurso coreográfico de una Fiesta y un Entierro que sirvió como estructura "performática" para ofrendar a los poderosos e influyentes mallkus, en su condición de dioses tutelares y antepasados venerados. Argumentamos nuestras conjeturas en torno a las dinámicas culturales que pudieron incluir la función social de la flauta que aquí estudiamos, pero somos conscientes que, musicalmente, sólo tenemos un testigo irrefutable: el sonido de un instrumento musical, el tono de los mallkus.

Agradecimientos: Por la colaboración brindada en el Museo de América de Madrid (España) para el estudio del material arqueológico musical que aquí se trata, nuestro agradecimiento va para Andrés Gutiérrez Usillos, María del Camino Barahona Fernández, Beatriz Robledo Sanz y Ana María Palacio Sánchez. Igualmente, agradecemos a Beatriz Débora Sajama y Armando Mendoza del Museo Dr. Eduardo Casanova de Tilcara, Jujuy (Argentina), a Jannice Rojas Vásquez y Gabriela Sotomayor del Área de Museos y Patrimonio de la Corporación de Cultura y Turismo, Calama (Chile); al colega Wilfredo Faundes Catalán por sus aclaraciones desde la arqueología experimental. Debemos mencionar, además, que las actividades de investigación en Chile fueron realizadas gracias al apoyo económico en el ítem Cooperación Internacional del Proyecto FONDECYT 1160849, dirigido por la segunda autora de este trabajo.

\section{Referencias}

Bertonio, Ludovico. 1612. Vocabvlario dela Lengva Aymara. Impresso en la casa de la Compañía de Iesus de Iuli Pueblo en la Prouincia de Chucuito. Por Francisco del Canto. Biblioteca Nacional del Perú. Biblioteca Digital Mundial. https://www.wdl.org/es/item/13776/.

Besom, Thomas. 2009. Of Summits and Sacrifice. An Ethnohistoric Study of Inca Religious Practices. Austin: University of Texas Press.

- 2010. "Inka sacrifice and the Mummy of the Salinas Grandes". Latin American Antiquity 21 (4): 399-422.

Boman, Eric. 1992. Antigüedades de la región andina de la República Argentina y del desierto de Atacama II. San Salvador de Jujuy: Universidad Nacional de Jujuy.

Fernández Distel, Alicia. 1997. Jujuy. Diccionario Arqueológico. Salta: Editorial Milor.

Gonçález Holguín, Diego. 2007 (1608). Vocabvlario de la Lengva General de todo el Perv llamada Lengua Qquichua, o del Inca. Edición digitalizada por Runasimipi Qespisqa Software con prólogo de Raul Porras Barrenechea de la versión de 1952. Lima.

Grebe, María Ester. 1974. "Instrumentos musicales precolombinos de Chile". Revista Musical Chilena 128: 5-55. 
Guaman Poma de Ayala, Felipe. 1615. El primer nueva corónica y buen gobierno. Ms. Gammel Kongelig Samling (GKS) 2232, 4․ Biblioteca Real de Dinamarca, Copenhague. http://www5.kb.dk/permalink/2006/poma/318/es/text/?open=idm45821230563376.

Guamán Poma de Ayala, Felipe. 1980 (1615). Nueva Corónica y Buen Gobierno. 2 tomos. Transcripción, notas, prólogo y cronología de Franklin Pease. Caracas: Biblioteca Ayacucho.

Gudemos, Mónica. 1998a. Antiguos sonidos. Jujuy: UBA Instituto Interdisciplinario Tilcara.

—. 1998b. "Flautas óseas precolombinas de la costa central de Perú, ¿organizaciones formales y sonoras preestablecidas?" Baessler-Archiv 46: 107-134.

—. 2000. "Módulos de afinación prehispanos". Baessler-Archiv 48: 43-105.

—. 2009. "Trompetas andinas prehispánicas. Tradiciones constructivas y relaciones de poder". Anales del Museo de América 17: 184-224.

—. 2018. Instrumentos musicales del Museo RP Gustavo Le Paige de San Pedro de Atacama (Chile) y del Área de Museos y Patrimonio de la Corporación de Cultura y Turismo, Calama (Chile). Informe del Proyecto FONDECYT 1160849 (Chile) y del Proyecto SeCyT UNC. N $33620180100470 \mathrm{CB}$ (Argentina).

Hornbostel, Erich M. von y Curt Sachs. 1914. "Systematik der Musikinstrumente. Ein Versuch". Zeitschrift für Ethnologie 46 (4/5): 553-590.

Horta Tricallotis, Helena. 2008. "Insignias para la frente de los nobles incas: una aproximación etnohistórica-arqueológica al principio de la dualidad”, en Lenguajes Visuales de los Incas, Paola González Carvajal y Tamara L. Bray, eds., pp. 71-89. Serie BAR S 1848. Oxford: Archaeopress.

—. 2011a. "El gorro troncocónico o chucu y la presencia de población altiplánica en el norte de Chile durante el período Tardío (ca. 1470-1536 d.C.)". Chungara 43 (1): 551-580.

—. 2011b. "Nuevos indicadores arqueológicos de la presencia altiplánica en Valles Occidentales durante el período Tardío", en Actas de la Reunión Anual de Etnología 23: 17-40. La Paz: Museo Nacional de Etnografía y Folklore.

-. 2015. El señorío Arica y los reinos altiplánicos (1000-1540 d.C.) Complementariedad ecológica y multietnicidad durante los siglos pre-conquista en el norte de Chile. Santiago: Ocho Libros Editores.

- 2016. "The Chin adornment of the Highland Lords as a Symbol of Historical Continuity and Ethnic Emblem in the Southern Andes (500-1600 AD)". Chungara 48 (3): 365-382.

Latcham, Ricardo. 1938. Arqueología de la región atacameña. Santiago: Prensas de la Universidad de Chile.

Lira, Jorge A. 1944. Diccionario Kkechuwa-Español. Tucumán: Universidad Nacional de Tucumán.

Martínez y Sáez, Francisco de Paula. 1994. Diario de Don Francisco de Paula Martínez y Sáez: Miembro de la Comisión Científica del Pacífico (1862-1865). Madrid: Consejo Superior de Investigaciones Científicas.

Mostny, Grete. 1957. "La momia del cerro El Plomo". Boletín del Museo Nacional de Historia Natural 27 (1): 3-127.

Murúa, Fray Martín de. 2004 (1590). Códice Murúa: Historia y genealogía de los reyes incas del Perú del padre mercedario Fray Martín de Murúa: Códice Galvin. Estudio de J. Ossio. 2 vols. Madrid: Testimonio Compañía Editorial.

Patané Aráoz, Claudio. 2015. "Una capacocha inca en Salinas Grandes (La Poma, Salta). El tupu y el plato del "Niño Muerto"...o ¿de la niña?". Estudios Sociales del NOA 16: 153-178. 
Pérez de Arce, José. 2007. Música Mapuche. Santiago de Chile: Fondo Nacional de Fomento del Libro y la Lectura, Consejo Nacional de la Cultura y las Artes.

Reinhard, Johan y María Constanza Ceruti. 2000. Investigaciones arqueológicas en el volcán Llullaillaco. Complejo ceremonial incaico de alta montaña. Argentina: Universidad Católica de Salta.

Sánchez Garrido, Araceli y Ana Verde Casanova, eds. 2003. Historia de un olvido. La expedición científica del Pacífico (1862-1865). Madrid: Ministerio de Educación, Cultura y Deporte.

Serrano, Antonio. 1930. Los Primitivos Habitantes del Territorio Argentino. Arqueología y Etnografía Argentinas. Buenos Aires: Librería y Editorial La Facultad. 